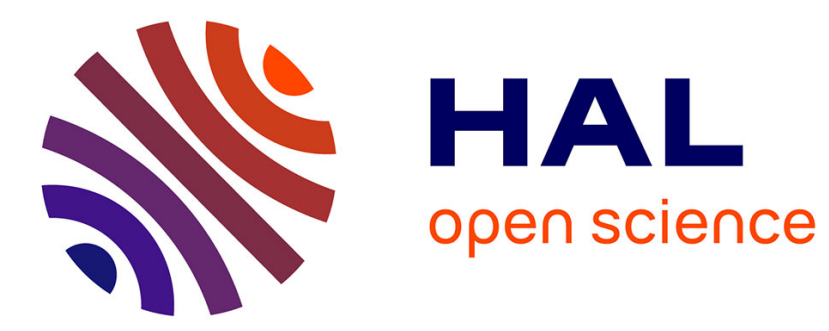

\title{
How indexicals function in texts: Discourse, text, and one neo-Gricean account of indexical reference
}

Francis Cornish

\section{To cite this version:}

Francis Cornish. How indexicals function in texts: Discourse, text, and one neo-Gricean account of indexical reference. Journal of Pragmatics, 2008, 40 (6), pp.997-1018. hal-00967884

HAL Id: hal-00967884

https://hal-univ-tlse2.archives-ouvertes.fr/hal-00967884

Submitted on 31 Mar 2014

HAL is a multi-disciplinary open access archive for the deposit and dissemination of scientific research documents, whether they are published or not. The documents may come from teaching and research institutions in France or abroad, or from public or private research centers.
L'archive ouverte pluridisciplinaire HAL, est destinée au dépôt et à la diffusion de documents scientifiques de niveau recherche, publiés ou non, émanant des établissements d'enseignement et de recherche français ou étrangers, des laboratoires publics ou privés. 
How indexicals function in texts: Discourse, text, and one neoGricean account of indexical reference

(Published in_Journal of Pragmatics 40(6), 2008, pp. 997-1018)

Francis Cornish

CNRS, CLLE-ERSS, UMR 5263

and University of Toulouse-Le Mirail,

Département Etudes du Monde Anglophone,

5, Allées Antonio Machado,

31058 Toulouse Cedex 09,

France.

Email: cornish@,univ-tlse2.fr 


\begin{abstract}
My goal in this article is to compare the behavior of a variety of non clausebound types of indexical expression in English across three texts from different genres, spoken as well as written. A key distinction is the one claimed to exist between the dimensions of text and discourse, and the comparison of the indexical types demonstrates its relevance. In a given text, certain lexically-specific types of indexical bearing an anaphoric interpretation may perform particular strategic, discourse unitdemarcating roles; while others realizing a deictic value may signal a shift in referential perspective, preparing the reader or addressee for a transition to a new discourse unit or sub-unit. Particularly highlighted are the deictic, anadeictic and anaphoric roles of the various indexicals as a function of text genre, utterer's intention and the interlocutive relationships developed throughout the discourse.

The article also assesses the neo-Gricean pragmatic account of (non-)coreference in discourse put forward in Levinson's (2000) Presumptive Meanings. The theory of Generalized Conversational Implicature, MIT Press. It argues that, rather than their discourse value being necessarily determined by the possibility of a choice between an attenuated and a prolix indexical type, it is the textual, contextual as well as discourse factors isolated during the earlier comparison which are adequate to describe and account for this.
\end{abstract}

Keywords: Text; Discourse; Context; Indexical; Deixis; Anaphora 


\section{Introduction}

In this article, I compare a variety of non clause-bound (i.e. "discourse") types of indexical expression in English across texts of different genres. I will be examining whole texts (spoken as well as written) which contain a wide range of indexical expressions (anaphors as well as deictics). The rationale here is that indexicals, whose raison d'être is to create discourse, are subject to a range of specifically discourse conditions and principles, as well as purely textual ones. ${ }^{\mathrm{i}}$

Starting out, then, by drawing a distinction between the dimensions of text and discourse, a distinction which will loom large in the article as a whole (§2), I will analyze three texts (both written and spoken) from different genres and will attempt to describe and account for the distribution of various types of discourse anaphors and deictics within and across various discourse units within them (§3). The text distributions of the various kinds of indexical expressions will be shown to reflect a delicate interaction between the semiotic properties of the expression types involved, the nature of the indexical reference, the genre of the text concerned, and the presence of competing equi-topical referents at the point of reference. In terms of discoursestructuring, we will see that certain types of indexical (in particular, reduced definite or demonstrative NPs and reduced repeated proper nouns, under an anaphoric interpretation) may fulfill a strategic, discourse unit-demarcating function; while certain demonstrative-based indexicals with a deictic interpretation may contribute to signaling a shift in referential perspective at points of transition between units.

My more major goal is to assess the extent to which one neo-Gricean approach to indexical reference, put forward in Levinson (2000), Huang (2000) and Blackwell (2003), is able to account for the data presented in an insightful way; or whether specifically discourse-structural properties and constructs are required to complement or even supersede such an account, as the case may be $(\S 4)$. It is the latter position which I will be arguing for in this final main section, as well as in the Conclusion.

\section{Text vs. Discourse}

Let us start by distinguishing between the dimensions of text and discourse (see Table 1 below).

Table 1: The respective roles of text, discourse and context (Cornish, 2003:3, slightly revised)

\begin{tabular}{|l|l|l|}
\hline \multicolumn{2}{|c|}{ Text } & \multicolumn{1}{|c|}{ Discourse } \\
\hline $\begin{array}{l}\text { The connected sequence of verbal } \\
\text { signs and non-verbal signals in } \\
\text { terms of which discourse is co- } \\
\text { constructed by the discourse } \\
\text { partners in the act of } \\
\text { communication. }\end{array}$ & $\begin{array}{l}\text { The product of the hierarchical, situated } \\
\text { sequence of utterance, indexical, } \\
\text { propositional and illocutionary acts } \\
\text { carried out in pursuit of some } \\
\text { communicative goal, and integrated } \\
\text { within a given context. }\end{array}$ & $\begin{array}{l}\text { The context (minimally, the domain } \\
\text { of reference of a given text, and the } \\
\text { specific utterance situation at hand) is } \\
\text { subject to a continuous process of } \\
\text { construction and revision as the } \\
\text { discourse unfolds. It is by invoking } \\
\text { an appropriate context (which is } \\
\text { partly determined by the co-text, as } \\
\text { well as by its genre) that the } \\
\text { addressee or reader may create } \\
\text { discourse on the basis of the } \\
\text { connected sequence of textual cues } \\
\text { that is text. }\end{array}$ \\
\hline
\end{tabular}

\footnotetext{
i See the distinction between the dimensions of text and discourse in Table 1 below. See also Widdowson (2004: Ch. 1).
} 
The text is the trace of at least one utterance act (whether realized in terms of a verbal, linguistic trace, or of a non-verbal one - which may be gestural, sensori-perceptual or prosodic). The notion of text is close to what Gumperz (1992:234) calls "contextualization cues": connected sequences of signs and signals pointing to possible ways of grounding the discourse to be constructed within a particular context ${ }^{\mathrm{ii}}$ in cognitive terms.

Discourse, on the other hand, refers to the hierarchically structured, mentally represented product of the sequence of utterance, propositional, illocutionary and indexical acts which the participants are jointly carrying out as the communication unfolds. Such sequences have as their prime objective the realization of a local and/or global communicative goal of some kind (see Parisi \& Castelfranchi, 1977). Discourse, then, is both hierarchical and defeasible (a provisional and hence revisable construction of a situated interpretation), whereas text is essentially linear - though in the spoken medium, paralinguistic, non-verbal phenomena may well co-occur simultaneously with the flow of verbal signs and signals.

'Meaning' does not lie completely "within" the text, it has to be constructed by the addressee (and the speaker!) via the text in conjunction with an appropriate context, including knowledge of the world, the genre of which the text at hand is an instance, as well as the social and communicative conventions which regulate the relevant language event. So the text is always incomplete and indeterminate in relation to the discourse which may be derived from it with the help of a context (cf. also Widdowson, 2004: 8; Jaszczolt, 2005: 13).

\section{Analysis of three sample texts from different genres}

\subsection{Deixis, anadeixis and anaphora}

A word is in order at the outset on the conceptions of deixis and anaphora I am adopting in this article. I am assuming here what is in my opinion a psychologically more realistic view of the distinction between these two discourse procedures than the traditional one. To my mind, deixis and anaphora are complementary discoursereferring procedures which the user exploits in constructing, modifying and accessing the contents of mental models of an unfolding discourse within the minds of speaker and addressee (or writer and reader in the written form of language).

In this more cognitively-oriented conception (cf. also Ehlich, 1982; Bosch, 1983; Lyons, 1977; Conte 1992, and Levinson, 2004), deixis serves prototypically to draw the addressee's attention focus to a new object of discourse (or to a new aspect of an existing one) that is derived by default via the situational context of utterance - whose center point is the 'here and now' of the speaker's verbal and non-verbal activity. Anaphora, on the other hand, is a discourse-referring procedure designed to continue the existing attention focus established hitherto (or assumed to be so established). Thus, anaphoric reference entails that the referents of (weakly stressed, phonologically nonprominent) indexicals are presupposed by the speaker to enjoy a relatively high degree of psychological salience or focus level at the point in the text where they are used. Both anaphora and deixis, then, operate at the level of memory organization, enabling

\footnotetext{
ii See Fetzer (2004) and Givón (2005) for the various types of context operating in text and discourse, as postulated by a range of different approaches to language use.
} 
the speaker to manage it by guiding the addressee's processing of incoming segments of a text.

Ehlich (1982) gives comparable definitions of the discourse-cognitive (orienting) functions of deixis and anaphora. See (1a) and (1b) below:

(1) a "Deixis is a linguistic ciii means for achieving focusing of the hearer's attention towards a specific item which is part of the respective deictic space”. (Ehlich, 1982: 325)

b "Anaphora is a linguistic means for having the hearer continue (sustain) a previously established focus towards a specific item on which he had oriented his attention earlier". (Ehlich, 1982: 330)

Deixis under this view may be seen as involving the use of the speech situation (the (deictic) ground, in Hanks', 1992 terminology) to profile a figure (a new referent or a new conception of an existing referent within the discourse registry); while anaphora consists in the retrieval from within a given ground of an already existing 'figure', together with its 'ground', the anaphoric predication acting to extend that ground (see Kleiber 1994: Ch. 3).

Canonical deixis and anaphora are but special instances on a cline of indexical reference ("pointing in context"), and are by no means mutually exclusive or "absolute" referring procedure types. As is well known, anaphora, both in phylogenetic and ontogenetic terms, is derivative upon deixis, which is the source of reference itself (cf. Lyons, 1975). Given that this is so, we may expect there to be a degree of overlap in between what we might term 'pure deixis', on the one hand, and 'pure anaphora', on the other. This is indeed the case. Pure deixis corresponds, for example, to the use of $1^{\text {st }}$ and $2^{\text {nd }}$ person personal pronouns (which may not have an anaphoric use), whereas pure anaphora is represented by the functioning of (unstressed) $3^{\text {rd }}$ person reflexive pronouns. These have an exclusively anaphoric function, and their use is grammatically constrained within the confines of the clause.

In between these two polar types of indexicals, we find a range of expression types (mainly demonstrative-based) which may be called "anadeictic" (see Ehlich, 1982:333-4 for this term). The use of one of these expression types involves partly anaphoric, and partly deictic reference. An example would be the "reminder" use of distal demonstrative determiners in English: Do you remember that holiday we spent together three summers ago in the Canary Islands? Here, there is a deictic aspect to the reference of the demonstrative NP (in that the speaker is clearly orienting the addressee's attention toward the shared representation of the holiday in question in long-term, episodic memory); but at the same time, there is an anaphoric dimension, since the use of the NP presupposes the prior existence of the shared representation within the addressee's memory. It is in no sense an attempt to construct such a memory representation, a situation which a canonical deictic reference would realize.

\subsection{National newspaper article}

Let us now attempt to apply these heuristic principles, first to a fairly simple attested text, a newspaper article which appeared in the British national newspaper The Guardian (3 May, 2000, p. 6). The article is reproduced in full as (2) below: ${ }^{\text {iv }}$

\footnotetext{
iii I would take issue with Ehlich, however, on the purported restriction of deixis to expression via linguistic means (though this is no doubt a correct characterization as far as anaphora is concerned). After all, deixis may well be realized via a gesture, or prosodically via a high pitch accent.
} 
Jon Henley in Paris

i. The proprietor of La Voile Rouge beach restaurant lodged a formal appeal yesterday against the decision by St Tropez town council to shut down one of the resort's most celebrated institutions, a favourite holiday haunt of such stars as Sylvester Stallone and Mick Jagger.

5.

The restaurant, built illegally on Pampelonne beach in the heady days of 1968 and $\boldsymbol{\emptyset}$
tolerated ever since, has been caught by a council campaign to clean up St Tropez's increasingly shabby image.

iii. La Voile Rouge's owner, Paul Tomaselli, 61, said he was challenging the legitimacy of the decision. 'The committee that rules on such things was supposed to be elected by proportional representation. In fact, it was appointed by simple majority vote; that's illegal, and

10. therefore all the committee's decisions are null and void.'

iv. But the council, fed up with complaints about the restaurant's loud music and the helicopters ferrying celebrities to and from a nearby helipad, is unlikely to let the matter rest.

v. 'The courts will decide $\boldsymbol{o}$, but in theory all these beach bars and restaurants should be bulldozed,' a spokesman said. 'They are ugly, noisy, not terribly safe, and completely illegal.

15. They have had a good run, but it is time to call it a day.'

vi. Mr Tomaselli's lawyer, Jean-Pierre Magnificat, said removing beach restaurants from St Tropez would be 'like banning waltzes in Vienna or beer in Munich'.

This is a typical journalistic text. It attempts to achieve a balance between two opposing positions (the writer "standing back" from the dispute at issue, not ostensibly taking one side or the other) - but at the same time to create a sense of controversy, suspense, and hence reader interest. The discourse structure reflects these two concerns, in terms of a 'Parallel Contrast' rhetorical structure: after a statement of the conflict in the first paragraph and a second one outlining the nature of the problem and its history, each subsequent paragraph apart from the fifth alternates between a representation of the position of the two main protagonists in the conflict - St Tropez town council, and the owner of La Voile Rouge beach restaurant (or his lawyer). However, the content of the fifth, a lengthy quotation from a council spokesman, has been given a separate paragraph for purely journalistic reasons. See Heurley $(1997: 182,185)$ on the differences between 'orthographic' and topic-based paragraphs. So this paragraph represents a mismatch between the complementary dimensions of text and discourse, as outlined in $\S 2$ above. (3) represents the discourse structure of text (2):

\section{(3) Discourse structure of text (2)}

\section{Unit Discourse function}

1. (Para (i)): Introduction of dual macro-topic: St Tropez town council's decision to close down La Voile Rouge beach restaurant, and the owner's formal appeal against it.

(1a) (Para (ii)): Continuation of macro-topic outline: explanation of origin of the problem, and justification of the council's decision.

2. (Para (iii)): Presentation of restaurant owner's position: the reason for his opposition to the decision (on a technical, legal point, rendering the ruling "null and void").

3. (Para (iv)): Presentation of council's position on the beach restaurant (loud music, frequent helicopter trips, neighbors' complaints).

\footnotetext{
${ }^{\text {iv }}$ Line numbers are given every five lines, and the paragraphs are each marked with a lower-case Roman numeral; the indexical expressions other than grammatically-determined ones (e.g. relative pronouns) are in boldface.

${ }^{\mathrm{v}}$ Indentations signal a subordinate sub-unit embedded within a more central discourse unit.
} 
(3a) (Para (v)): Council spokesman's further explanations, on beach restaurants in general.

4. (Para (vi)): Coda: Rejection by lawyer representing restaurant owner of this negative view of beach restaurants (they are an accepted part of the culture of St Tropez).

There is little in the way of deixis apparent in this text. The only occurrences appear in line 1 (the primary deictic-signaling temporal expression yesterday) and in the direct speech segments quoted: the distal demonstrative pronoun that in line 9 as used by the restaurant owner, Paul Tomaselli (this may be analyzed as an instance of "discourse deixis": see Webber, 1991), and the universally quantified proximal demonstrative NP all these beach bars and restaurants, quoted directly from the council spokesman in line 13 - an instance of what Ehlich (1982) terms "anadeixis" (there is another instance of this in text (6) below). This anadeictic reference, designating beach bars and restaurants of the La Voile Rouge type in general, has a macro-discourse function in that it serves precisely to extrapolate from this particular case to the more global issue of beach bars and restaurants, and thus to herald a shift to the Coda (which evokes the issue in more general socio-cultural terms), so bringing the discourse to a close.

In terms of the anaphoric functioning of the majority of indexical expressions in this text, it is clear that the ones most frequently used to sustain reference to the major topic entities evoked are definite full NPs and not pronouns. This is partly due to the journalistic genre of the text, which favors the use of full NPs generally, and partly to the fact that a number of these anaphoric references tend to have an important strategic, 'signposting' function within the text as a whole - cf. also Francis' (1986) notion "anaphoric nouns" in this connection. That is, they signal the start of a new central discourse unit (or a dependent subunit) - cf. Fox (1987) in relation to repeated proper nouns in particular - and serve to 'ground' the content of that unit or subunit.

In paragraphs (ii) (subunit 1a of the discourse, line 4), (iii) (unit 2, line 7) and (iv) (unit 3, line 11) we find either a "renaming" (cf. Schnedecker, 1997) proper noun (la Voile Rouge in line 7) or reduced definite NPs (the restaurant in line 4, the council in line 11) which introduce new units or subunits. In the case of the full NPs the restaurant and the council, a $3^{\text {rd }}$ person pronoun could not have occurred in their place, since these expressions are each modified by an appositive clause (a reduced nonrestrictive relative).

$3^{\text {rd }}$ person pronouns or zeros are not intrinsically capable of fulfilling this "announcing" or signposting function — though they may well occur initially in subunits (there is even an example in text (4) of a zero pronoun introducing a full unit: the zero subject of sounds in line 21, introducing unit 4). The tacit instruction associated with the occurrence of tokens of this form type is to continue the psychological focus of the preceding textual unit. Indeed, the only pronouns which occur (he, it, that in paragraph (iii), they (twice) in paragraph (v)) refer to entities introduced within the units or subunits in which they appear. However, the zero pronoun object of decide in line 13 (the courts will decide ø) is an exception to this generalization, since it refers back to a major topic entity within the discourse as a whole ('the dispute between St. Tropez Town Council and Paul Tomaselli').

Table 2 summarizes the distributions of the various indexical expressions in text (2), whether anaphoric or deictic in function, in terms of their position within the relevant discourse units or subunits. 
Table 2: Distributions of various types of indexical expression in terms of position within discourse units, in text (2). The percentages indicated are in relation to the set of expression types considered within a given row.

\begin{tabular}{|c|l|l|l|l|l|l|l|l|}
\cline { 2 - 9 } \multicolumn{1}{c|}{} & $\begin{array}{l}\text { Reduced } \\
\text { Prop N }\end{array}$ & $\begin{array}{c}\text { Dem } \\
\text { lex NP }\end{array}$ & $\begin{array}{l}\text { Def lex } \\
\text { NP }\end{array}$ & $\begin{array}{l}\text { Dem } \\
\text { pron }\end{array}$ & $\begin{array}{c}\text { Poss } \\
\text { lex } \\
\text { NP }\end{array}$ & $\begin{array}{c}\text { 3rd pers } \\
\text { pron }\end{array}$ & $\begin{array}{c}\text { Zero } \\
\text { anaphor }\end{array}$ & Totals \\
\hline $\begin{array}{c}\text { Unit/Subunit } \\
\text { initial } \\
\text { position }\end{array}$ & $\begin{array}{l}2 \\
(50 \%)\end{array}$ & 0 & $\begin{array}{l}2 \\
(50 \%)\end{array}$ & 0 & 0 & 0 & & \\
\hline $\begin{array}{c}\text { Unit-medial } \\
\text { positions }\end{array}$ & 0 & 2 & 5 & 1 & & 4 & 2 & $\begin{array}{l}4 \\
(100 \%)\end{array}$ \\
\hline Totals & 2 & $(14.2 \%)$ & $(35.7 \%)$ & $(7.1 \%)$ & 0 & $(28.5 \%)$ & $(14 . \%)$ & $(100 \%)$ \\
\hline
\end{tabular}

\subsection{Advertisement in the form of a circular letter}

Here now is another written text, but from a completely different genre (in fact its genre is hybrid): an advertisement, in the form of a circular letter to UK householders. It takes the shape of a formal, written letter. ${ }^{\mathrm{vi}}$ Yet this text adopts many features typical of informal, spoken discourse. This feature is clearly a reflection of the advertiser's desire to gain the reader's attention, interest and continued mental contact: the phatic communicative function is much in evidence throughout this text.

\author{
INSUGLAZING FROM \\ A l p i n e \\ HOME IMPROVERS TO THE \\ HOUSEHOLDS OF BRITAIN
}

\author{
ALPINE (DOUBLE- \\ GLAZING) CO LTD \\ ALPINE HOUSE \\ HONEYPOT LANE \\ LONDON NW 99 RU 01- \\ 2043393
}

TELEX: 923617

Dear Householder

i. Ever thought about installing beautiful patio doors in your house? Ever wondered how much they would cost, how long it would take, and what the real advantages $\boldsymbol{\emptyset}$ would be? Then this

5. letter could be important to you.

ii. Alpine - the experts in double glazing - are working in your neighbourhood right now. What better time for you to find out the facts from the recognised professionals?

iii. The Alpine system of double glazing is called InsuGlazing. It's the ultimate in double glazing, with so many advantages, including a special white electrophoretic surface

10. that's extremely durable, $\boldsymbol{\varnothing}$ needs no painting for years, and $\boldsymbol{\emptyset}$ wipes clean with a soft cloth.

iv. Your sliding patio doors will transform your house into a light, airy summer home you can really enjoy, and $\boldsymbol{\varnothing}$ give you so much more room to live and breathe in. In winter, of course, they'll still let you appreciate your garden view to the full and o provide you with a warmth and comfort that old doors or badly fitting French windows never can $\boldsymbol{\emptyset}$.

15. v. The cost? It's hard to be precise in this letter, because every installation is different from the next, and Alpine insist on thorough measurement and discussion with you before we provide our free estimate. We insist on supervising our own work, too.

vi. Alpine superior patio doors may cost less than you think, however. It will certainly cost you nothing to find out $\boldsymbol{\sigma}$, and there is an Alpine home improvement plan to spread your payments

20. over 5 years if you wish $\mathbf{0}$, which could qualify for tax relief.

\footnotetext{
${ }^{\mathrm{vi}}$ Witness the name and address of the sender in the top right-hand corner, and the form of address adopting the conventional opening and closing formulas Dear Householder, Yours faithfully, followed by the sender's name and signature.
} 
vii. Ø sounds attractive? Patio doors by Alpine are attractive, and they make sense, especially right now.

viii. Don't leave it any longer. Benefit now with InsuGlazing from Alpine - the ultimate in double glazing.

Yours faithfully,

(Signature)

Kenneth Hyman

$\underline{\text { Sales Director }}$

(5) gives the discourse structure which may be associated with this letter-advertisement.

\title{
(5) Discourse structure of text (4)
}

\author{
Unit $\quad$ Discourse Function \\ 1 (Para (i)) Phatic: establish communicative contact with reader-addressee of \\ the letter-advertisement. \\ 1a: (Para (ii)): Identification of addressor + their location. \\ 2 (Para (iii)) Description of nature of product being advertised + its claimed \\ advantages. \\ 2a: (Para (iv)): Continuation of description of advantages of patio \\ doors (a) in summer, and (b) in winter. \\ (Para (v)) Cost of installing patio doors + product (not provided). \\ 3a: (Para (vi)) Continuation of cost issue: availability of finance Plan \\ to spread out payment. \\ (Para (vii)) Coda: re-emphasis on attractiveness of product advertised. \\ 4a: (Para (viii)): Final appeal to reader/targeted customer.
}

The discourse structure associated with this text consists of four basic units, as in text (2): the first two paragraphs fall together in providing an "entrée" into the matter of the letter, contextualizing or grounding it as a message by establishing both the intended addressee and the nature of the locutionary source (the double-glazing firm "Alpine"). The next two major units are basically descriptive or content-orientated, concerned with the product being advertised, and its claimed advantages for the buyer (unit 2), then with the issue of the cost of the product and its installation, and how it would be established taylor-made for the customer and possibly met (unit 3). The final unit is a coda, spurring the reader to act by taking up the offer (or requesting further details). Each unit is realized by two textual paragraphs.

Given the context and hybrid genre of this letter-advertisement, it is not surprising to find that there are a great many deictic or quasi-deictic indexical references - a state of affairs which contrasts radically with that evident in text (2), where the majority of deictic or quasi-deictic references (only amounting to three in total) occurred in reported direct speech segments. In text (4), the conative function is very much in evidence (frequent explicit references to addressee: you, your, ellipsis of $2^{\text {nd }}$ person subject + auxiliary in polar interrogatives, as well as to addressor (we, our)). There are discourse-deictic self-references to the text itself (this letter, paras (i) and (v)) as well as pure-deictic references to the time of utterance/time of reception (right now, paras (ii) and (vii), now, para (viii)). These deictic references occur particularly within the discourse units whose essential function is phatic (the initial and final units 1, paras (i) and (ii), and 4 , paras (vii) and (viii)), but $1^{\text {st }}$ and $2^{\text {nd }}$ person pronoun references also occur throughout. 
Three further deictic references are worthy of mention here. The first is the reference to the firm advertising the product in question ("Alpine") at the head of paragraph (ii) (subunit 2a, line 6): Alpine - the experts in double glazing - followed by the plural form of the verb of which this NP is the subject (are working): see Bock et al. (2006) for discussion of plural marking on verbs whose subject is headed by a collective noun. The plural marking on the verb indicates that the subject's referent is to be construed "agentively", distributively, rather than collectively as an abstract entity. A further quasi-deictic reference occurs in the next sentence: the recognised professionals, an NP whose referent is anaphorically expanded to the context domain "...in doubleglazing". vii The first reference takes the form of a proper noun followed by an appositional definite description, and the second, of a definite NP; but both are construed deictically in virtue of their reference to the firm issuing this circular letter.

The third such reference occurs in para (vii), the letter's coda, at the head of this unit: $\varnothing$ sounds attractive?. This is a discourse-deictic reference via a null subject (a feature of a spontaneous speech style - there being a great many features of this kind throughout the text) to the illocutionary point of the preceding discourse: the outline of all the advantages of sliding patio double-glazed doors. It has a macro-discourse function in signaling a shift in the structure of the discourse from the two central units 2 and 3, dealing with the nature of the product on offer, to the effect this is intended to have on the reader/potential customer, and the final appeal in the letter's coda.

As in the newspaper article in (2), (definite) lexically-headed NPs occur unit initially, signaling both the shift in discourse structure at these points and the essential content of the new units. Witness The Alpine system of double glazing at the head of unit 2 (line 8), the possessive demonstrative NP Your sliding patio doors in subunit 2a (line 11), the anaphoric (referentially dependent, non autonomous) NP The cost introducing unit 3 (line 15), and the indefinite, non-indexical NP Alpine superior patio doors at the head of subunit 3 a (line 18). These unit- or subunit-initial references have both a backward- and a forward-looking function within the discourse.

As also in text (2), from a very different genre, $3^{\text {rd }}$ person pronouns and zeros ${ }^{\text {viii }}$ function only within units or subunits: see they, it and the zero complement of the noun advantages in para (i), unit 1 , it and the two occurrences of zero subjects in para (iii) (unit 2), the zero subject and complement as well as the pronoun they in para (iv) (subunit 2a), the two zero complements in para (vi) (subunit 3a), the pronoun they in para (vii) (unit 4) and the "anadeictic" it in para (viii) (unit 4a). Apart from the zero subject of sounds in line 21, none of these attenuated indexical form tokens refers across discourse units, or even subunits.

Table 3 summarizes the distributions of the various indexical expressions in text (4), as a function of their discourse-unit position.

\footnotetext{
vii Via Levinson's (2000) "I" principle, expanding given references to contextually default stereotypical entities: see item (8) in section 4 below.

viii With the exception of the zero subject of sounds in line 21, which opens unit 4.
} 
Table 3: Distributions of various types of indexical expression in terms of position within discourse units, in text (4). The percentages indicated are in relation to the set of expression types considered within a given row.

\begin{tabular}{|c|c|c|c|c|c|c|c|c|c|}
\hline & $\begin{array}{l}\text { Reduced } \\
\text { Prop N }\end{array}$ & $\begin{array}{c}\text { Dem } \\
\text { lex NP }\end{array}$ & $\begin{array}{l}\text { Def lex } \\
\text { NP }\end{array}$ & $\begin{array}{c}\text { Poss } \\
\text { lex } \\
\text { NP }\end{array}$ & $\begin{array}{l}\text { Dem } \\
\text { pron }\end{array}$ & $\begin{array}{c}\text { 3rd pers } \\
\text { pron }\end{array}$ & $\begin{array}{c}\text { Zero } \\
\text { nom } \\
\text { anaphor }\end{array}$ & $\begin{array}{c}\text { Zero } \\
\text { VP } \\
\text { anaphor }\end{array}$ & Totals \\
\hline $\begin{array}{c}\text { Unit/Subunit } \\
\text { initial } \\
\text { position } \\
\end{array}$ & $\begin{array}{l}1 \\
(14.2 \%) \\
\end{array}$ & $\begin{array}{l}2 \\
(28.5 \%) \\
\end{array}$ & $\begin{array}{l}3 \\
(42.85 \%) \\
\end{array}$ & 0 & 0 & 0 & $\begin{array}{l}1 \\
(14.2 \%)\end{array}$ & 0 & $\begin{array}{l}7 \\
(100 \%) \\
\end{array}$ \\
\hline $\begin{array}{l}\text { Unit-medial } \\
\text { positions }\end{array}$ & $\begin{array}{l}3 \\
(7.8 \%) \\
\end{array}$ & $\begin{array}{l}7 \\
(18.4 \%) \\
\end{array}$ & $\begin{array}{l}3 \\
(7.8 \%) \\
\end{array}$ & 0 & $\begin{array}{l}12 \\
(31.5 \%) \\
\end{array}$ & $\begin{array}{l}6 \\
(15.7 \%) \\
\end{array}$ & $\begin{array}{l}4 \\
(10.5 \%) \\
\end{array}$ & $\begin{array}{l}3 \\
(7.8 \%) \\
\end{array}$ & $\begin{array}{l}38 \\
(100 \%) \\
\end{array}$ \\
\hline Totals & $\begin{array}{l}4 \\
(8.8 \%)\end{array}$ & $\begin{array}{l}9 \\
(20 \%)\end{array}$ & $\begin{array}{l}6 \\
(13.3 \%)\end{array}$ & 0 & $\begin{array}{l}12 \\
(26.6 \%)\end{array}$ & $\begin{array}{l}6 \\
(13.3 \%)\end{array}$ & $\begin{array}{l}5 \\
(11.1 \%)\end{array}$ & $\begin{array}{l}3 \\
(6.6 \%)\end{array}$ & $\begin{array}{l}45 \\
(100 \%)\end{array}$ \\
\hline
\end{tabular}

\subsection{Oral eye-witness account of a natural disaster}

The third and final text I am presenting for analysis is an oral eye-witness account of the tsunami wave disaster of December 2004 as it affected the town of Patong in Thailand (from the $B B C$ News on the $W e b, 27^{\text {th }}$ December, 2004). It is a monologue which was recorded shortly after the event, and is full of subjective responses and reactions - but it takes into account the intended addressees. The genre is therefore that of spoken narrative monologue.

\section{(6) Eyewitness: Panic in Patong}

Thousands of people have been e-mailing the BBC News website about horrific experiences as sea surges hit their homes and holiday retreats.

Troy Husum, a 28-year-old Canadian, was on holiday in Phuket, Thailand. He spoke of the devastation as the waves hit the town of Patong and how survivors are coping.

I felt the quake first at about 0915.

i. I went out on my balcony in the hotel where I was staying - it was a beautifully calm day - and talked to others on their balconies. The quake felt very slight so we thought little of it.

ii. About 45 minutes later, I noticed that water had receded from Patong Bay. We'd never seen it

5. before and we could hear people on the beach talking about it. You could even see fish flopping around on the beach, which was unusual.

iii I noticed small kids and tourists walking to where the water had receded, curious as to why the water had gone.

iv. Then I saw it - I noticed people craning their necks and looking out on the horizon. You could see

10. a wall of water about three or four stories high.

v. I felt like I was watching a movie, it was completely surreal.

vi. It wasn't moving very quickly, it took between four and five minutes until I saw it hit $\mathbf{m}$ and in that time slowly people started to realise what was happening.

vii. People were saying 'Oh God, what is that?' I thought I was dreaming.

15.viii. After a few seconds the wave hit $\boldsymbol{\varnothing}$ and $\boldsymbol{\emptyset}$ smashed against the beach.

ix. It was incredible, it actually bent the trees, washed everything away - at least 1,000 beach umbrellas were swept along as all the water surged through.

$\mathrm{x}$. There is a line of cars where people park by the beach and hundreds of bikes, I saw them all picked up like toys and $\boldsymbol{\emptyset}$ moved along.

20.xi. Most disturbing was I saw people literally disappear when the water hit $\boldsymbol{\emptyset}$.

xii. I saw a lot running, but there were people snoozing on the beach, I saw small children hit. People were literally swept away. 
xiii. A lot of injuries occurred from people being hit by debris from cars, from bikes.

\section{Running for safety}

xiv. I thought I should get some pictures because I was staying on the fourth floor of my hotel, but people on the balconies said we had to get on the roof.

xv. I grabbed my equipment and ran outside into the hall. People were screaming "Go! Go!" I ran

30. up the stairs and saw the water coming.

xvi. It flowed up to the third floor, you could see it in the stairwell, some people were completely wet.

xvii. We watched the chaos from the roof. The water had already started to recede as we got there.

xviii. The hardest part for survivors was actually when water receded - the undercurrent sucked

35. people back into the ocean.

Bodies

xix. The most frightening part was not the wave - it was the panic that ensued.

40. $\mathrm{xx}$. There were car accidents, people were trying to escape as everyone was positive another wave was coming.

xxi. People - mainly local Thais - went up the roads to the mountain and slept up there for safety.

xxii. Within an hour I went back to the beach. I saw bodies. The rescue crews were panicking and there was not much control.

45. xxiii. Bodies were pulled from the debris - most had clearly drowned. I also saw a number of fractures - one tourist had a very badly broken arm.

xxiv. You could constantly hear helicopters - they flew up to about one kilometre out to sea to try to rescue people.

xxv. Last night most hotels allowed tourists to sleep for free in their lobbies or by the pool and

50. there was still a lot of fear and misinformation about other waves.

\section{Aftermath}

xxvi. This morning the cleanup started. All the foreigners are in disbelief, there are two or three

55. feet of sand in all these devastated restaurants.

xxvii. There are piles and piles of rubble deep inland - it looks like a bomb has gone off.

xxviii. Some bars I went to the night before on the beach are completely gone. All of the palm trees were flatted (sic) or removed. How is water capable of doing that?

xxix. They are carting out hundreds of cars and bikes and the streets are still covered with sand.

60. xxx. They really should have cordoned off the streets. There has been a little looting, some last night and today. I saw guys with televisions and computers.

xxxi. There are people staggering around with injuries, I saw a girl with bandage on her head. Today there have also been sirens which have now died down.

xxxii. They are still pulling people out of the debris. One was a small Thai girl - she must have

65. been there all night but she was still alive.

This text's discourse structure is given in (7) below. Observe that this structure does not correspond point by point to the divisions made by the BBC journalist in terms of section headings: though units 1 and 2 of the discourse (see item (7) below) correlate with the points in the text indicated by the first section heading ("Running for safety") up to the second ("Bodies"), the third unit is a conflation of the third and fourth sections (marked by the latter section title and by the title "Aftermath", respectively). This third macro-discourse unit deals more globally with the consequences of the tidal wave in the area. As in the case of paragraph divisions (see the discussion of text (2) in §3.2), it is clear that the journalist has inserted section titles "after the fact", in order to ensure ease of reading as $\mathrm{s} /$ he saw it.

\section{(7) Discourse structure of text (6)}




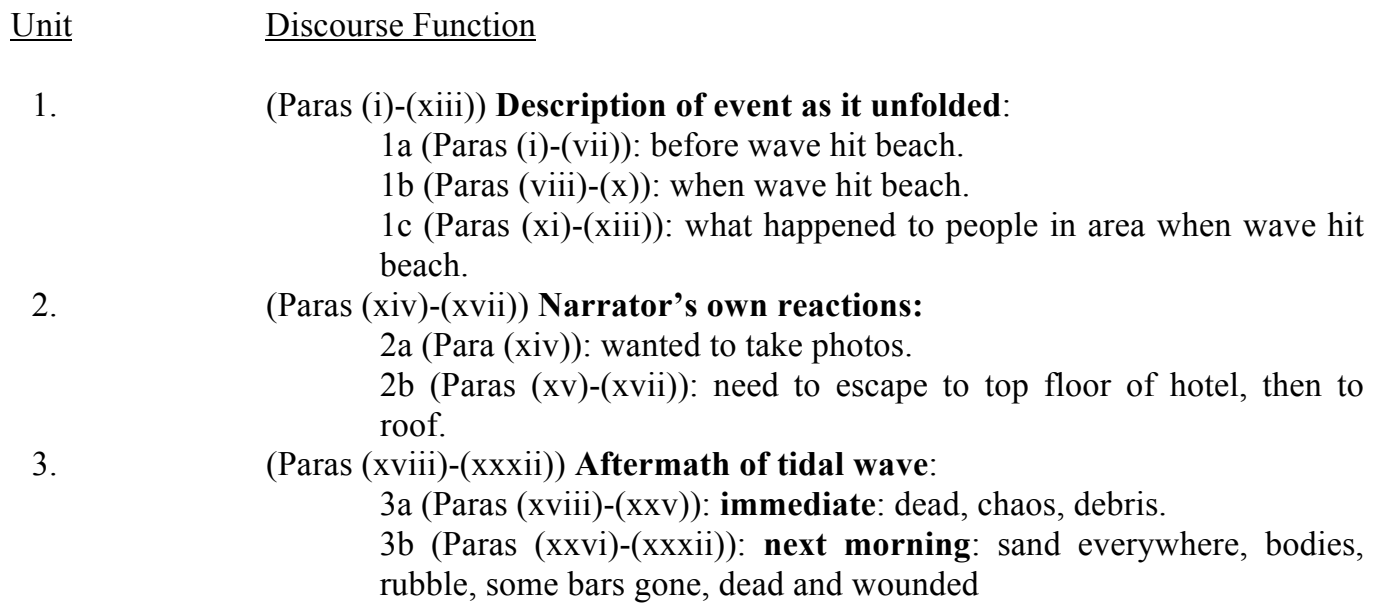

This originally oral text is relatively unstructured, being more or less unplanned (certainly in comparison to the two written texts presented earlier). As we have partly seen, the title, header, lead-in and sub-headings have clearly been provided by the BBC journalist. The text type is thus the exact opposite of the letter-advertisement presented as (4): whereas (4) is basically a written text taking the shape of a formal written letter, but in actual fact the language used in it is more typical of relaxed oral conversation (corresponding to the type of discourse relationship the addressor is seeking to establish with the intended readers), (6) is basically a spoken (monologue) text. However in its written form, it has an overlay of presentational-structural devices typical of printed news journalism.

The discourse is organized on a chronological basis - an account of the events as they happened: the quake, the tidal wave which ensued (in its various stages of development), the eye-witness's reactions (as well as those of people around him at the time), and the consequences of the wave's breaking which were visible on the shoreline and the buildings and town of Patong the following day. So the structure is a relatively loose one, typical of unplanned, or semi-planned (as in this case) discourse - a "chronological" discourse structure, organized in terms of a purely temporal sequence of events, being the weakest type of integrative framework for a given discourse.

What is striking about this text, in terms of its use of indexical expressions, is the very high proportion of reduced definite NPs in relation to pronouns, zeros, elliptical expressions and demonstratives (see Table 4 below for details). In this, it is like the two planned written texts in (2) and (4). There are 39 tokens of reduced definite NPs (some with deictic reference, but most of the associative-anaphoric kind), $203^{\text {rd }}$ person pronoun tokens (it, them, they, she and the elliptical one, a lot and most), 4 zeros, 50 demonstratives (9 demonstrative NPs and 41 demonstrative pronouns - mainly $1^{\text {st }}$ and $2^{\text {nd }}$ person), and finally 4 instances of possessive NPs.

Many of the definite NPs have an "associative-anaphoric" function (see for example the numerous references to parts of the hotel where the narrator was staying: e.g. the balconies, the stairs, the stairwell, the pool, the hall; as is well known, such references are normally realized via definite lexical NPs). However, the definite NPs in text (6) do not pattern in the same way as their equivalents in the other two texts. For in terms of discourse-unit distribution, clearly the great majority of occurrences of definite lexical NPs are found in unit-medial, and not unit-initial positions: ${ }^{\text {ix }}$ definite lexical NPs account for only $16.6 \%$ of the unit-initial occurrences of indexical expressions, as

\footnotetext{
${ }^{\mathrm{ix}}$ Unlike the situation in texts (2) and (4), relatively speaking, where the reverse relationship is evident: see the "definite lexical NP" cells in Tables 2 and 3 in this respect.
} 
against $35.2 \%$ of all unit-medial ones. This is no doubt due in part to the fact that, unlike texts (2) and (4), text (6) is only semi-planned: not only are its units not so sharply demarcated as in the case of the other two texts, ${ }^{x}$ but, given this fact, there is correspondingly less need to "announce" the essential content and communicative function of these units.

There is more deixis apparent in text (6) than in text (2), a factor which aligns text (6) more closely with text (4): apart from the frequent instances of temporal deixis realized by dedicated demonstrative-based expressions (e.g. last night, this morning, today, all night), there are frequent occurrences of $1^{\text {st }}$ person personal pronouns $(I$, we). But unlike the situation evident in text (4), the $2^{\text {nd }}$ person personal pronouns used are all generic in status, referring to the prototypical observer rather than to an actual addressee. This is clearly a reflex of the fact that, unlike text (4), text (6) is monologual and not dialogual in character, the narrator simply recounting the dramatic events he has witnessed for a wider, more "impersonal" public.

In addition, several instances of definite lexical NPs have a deictic value via their referent's being located at or near the place of utterance (e.g. the beach, lines 5, 6, $15,18,21,43$ and 57; the debris, lines 45 and 64). There is an instance of discourse deixis in line 14 realized by the distal demonstrative pronoun that (no doubt contrastively stressed in its original use), as uttered by the people witnessing the tsunami from the beach; and an "anadeictic" occurrence of a demonstrative-based NP, all these devastated restaurants, in line 55. In this respect, see the near identical universally quantified demonstrative NP used in text (2), line 13, which has a very similar discourse function: viz. all these beach bars and restaurants. For together with the time-shifting temporal proximal demonstrative NP this morning in line 54, the universally quantified proximal locative demonstrative NP in text (6) serves to move the time and place coordinates characterizing sub-unit $3 a$ to those relevant to sub-unit $3 b$, thereby effecting a transition to it. Section 4 below analyzes certain of the reduced definite NPs in this text.

Table 4: Distributions of various types of indexical expression in terms of position within discourse units, in text (6). The percentages indicated are in relation to the set of expression types considered within a given row

\begin{tabular}{|c|c|c|c|c|c|c|c|c|c|}
\hline & \begin{tabular}{|l|} 
Reduced \\
Prop N
\end{tabular} & $\begin{array}{c}\text { Dem } \\
\text { lex NP }\end{array}$ & $\begin{array}{l}\text { Def lex } \\
\text { NP }\end{array}$ & $\begin{array}{c}\text { Poss } \\
\text { lex NP }\end{array}$ & $\begin{array}{l}\text { Dem } \\
\text { pron }\end{array}$ & $\begin{array}{c}3 \text { rd pers } \\
\text { pron }\end{array}$ & $\begin{array}{l}\text { Zero } \\
\text { nom } \\
\text { anaphor }\end{array}$ & $\begin{array}{c}\text { Zero } \\
\text { VP } \\
\text { anaphor }\end{array}$ & Totals \\
\hline $\begin{array}{c}\text { Unit/Subunit } \\
\text { initial } \\
\text { position } \\
\end{array}$ & 0 & \begin{tabular}{|l}
1 \\
$(8.3 \%)$ \\
\end{tabular} & $\begin{array}{l}2 \\
(16.6 \%) \\
\end{array}$ & 0 & $\begin{array}{l}8 \\
(66.6 \%) \\
\end{array}$ & \begin{tabular}{|l}
1 \\
$(8.3 \%)$
\end{tabular} & 0 & 0 & $\begin{array}{l}12 \\
(100 \%) \\
\end{array}$ \\
\hline $\begin{array}{c}\text { Unit-medial } \\
\text { positions }\end{array}$ & 0 & \begin{tabular}{|l|}
8 \\
$(7.6 \%)$ \\
\end{tabular} & \begin{tabular}{|l}
37 \\
$(35.2 \%)$ \\
\end{tabular} & \begin{tabular}{|l}
4 \\
$(3.8 \%)$ \\
\end{tabular} & $\begin{array}{l}33 \\
(31.4 \%) \\
\end{array}$ & \begin{tabular}{|l}
19 \\
$(18.1 \%)$ \\
\end{tabular} & $\begin{array}{l}4 \\
(3.8 \%) \\
\end{array}$ & 0 & $\begin{array}{l}105 \\
(100 \%) \\
\end{array}$ \\
\hline Totals & 0 & $\begin{array}{l}9 \\
(7.6 \%) \\
\end{array}$ & \begin{tabular}{|l}
39 \\
$(33.3 \%)$ \\
\end{tabular} & $\begin{array}{l}4 \\
(3.4 \%) \\
\end{array}$ & $\begin{array}{l}41 \\
(35 \%) \\
\end{array}$ & $\begin{array}{l}20 \\
(17 \%) \\
\end{array}$ & $\begin{array}{l}4 \\
(3.4 \%) \\
\end{array}$ & 0 & $\begin{array}{l}117 \\
(100 \%) \\
\end{array}$ \\
\hline
\end{tabular}

\section{Analysis of the functioning of various anaphor types in terms of Levinson's (2000) "I-" and "M-" principles}

Levinson (2000) presents a particular neo-Gricean pragmatic theory of Generalized Conversational Implicatures, based on three meta-principles (Informativeness, Manner

\footnotetext{
${ }^{\mathrm{x}}$ After all, it is the BBC journalist who has inserted the section headings, after the fact, in text (6).
} 
and Quantity: respectively abbreviated as "I-", "M-" and "Q-" principles). Generalized Conversational Implicatures are said to be virtually automatic, quasi-default inferences not dependent on any particular context for their existence; whereas Particularized Conversational Inferences are so dependent, and by hypothesis require "working out" on the part of the addressee or reader. Both types of implicatures are "defeasible", that is, cancelable without contradiction in the light of real-world or lexical knowledge, or of subsequent discourse or contextual factors. See Levinson (2000: 16-21) for arguments in favor of the distinction between GCIs and PCIs; but see Jaszczolt (2005: 24-28, 4043) for arguments against viewing GCIs, as conceived by Levinson, as constituting a theoretically homogeneous category. In particular, the three meta-principles are claimed to account (among other things) for the actually existing distributions of different types of anaphoric (or more generally, indexical) expressions in texts. Huang (2000) is an attempt to apply a version of this theory to a range of examples from a variety of languages, and Blackwell (1998), (2000), (2001), (2003) to a range of anaphor types ${ }^{x i}$ in naturally occurring Castilian Spanish conversational and spoken narrative discourse.

The I-principle is said to induce default, stereotypical interpretations (Levinson, 2000: 157). It is stated in full as (39) on pp. 114-115:

\footnotetext{
I-Principle

Speaker's maxim: the maxim of Minimization. "Say as little as necessary"; that is, produce the minimal linguistic information sufficient to achieve your communicational ends (bearing $\mathrm{Q}$ in mind).

Recipient's corollary: the Enrichment Rule. Amplify the informational content of the speaker's utterance, by finding the most specific interpretation, up to what you judge to be the speaker's m-intended point ${ }^{\mathrm{xii}}$, unless the speaker has broken the maxim of Minimization by using a marked or prolix expression. Specifically:

a. Assume the richest temporal, causal and referential connections between described situations or events, consistent with what is taken for granted.

b. Assume that stereotypical relations obtain between referents or events, unless this is inconsistent with (a).

c. Avoid interpretations that multiply entities referred to (assume referential parsimony); specifically, prefer coreferential readings for reduced NPs (pronouns or zeros).

d. Assume the existence or actuality of what a sentence is about if that is consistent with what is taken for granted.
}

According to this principle, speakers tend to provide the minimum amount of information needed, consistent with the general direction of the exchange, while their addressees are supposed to infer from each utterance a more specific, more fully informative interpretation. xiii

The "M-Principle", which is complementary to the I-Principle, is stated on pp. 136-7 as (69). This principle basically says that the use of a marked expression in place of an otherwise possible unmarked one which would have I-implicated the corresponding normal, stereotypical situation, tends to signal the speaker's intention to convey a marked interpretation.

\footnotetext{
xi Subject zeros, non clitic reflexives, overt $3^{\text {rd }}$ person and demonstrative pronouns, and definite and demonstrative NP anaphors.

xii "M-intention" denotes the speaker's intention to cause an effect in the recipient by getting him or her to recognize that such was his/her intention (cf. Levinson, 2000: note 43 to Ch. 2, p. 391).

xiii See the text/discourse distinction drawn in Table 1, where the text underdetermines the discourse derivable from it in conjunction with an appropriate context.
} 
Now, if we consider the potential choice in a given position between a $3^{\text {rd }}$ person pronoun and a lexically more explicit expression (a reduced definite lexical NP, for example), then the situation would seem not to be entirely clear-cut, following these two meta-discourse principles. For on the one hand, Levinson points out that reduced definite lexical NPs may convey the stereotypical interpretation consonant with an Iimplicature, indicating local coreference (as in his example (42a), given as (9) below):

(9) The ferry ${ }_{1}$ hit a rock. The ship ${ }_{1}$ capsized. $^{\text {xiv }}$ (Levinson, 2000: example (42a), p. 225)

Yet on the other hand, the same type of general definite lexical NP is used as an example of the application of the M-Principle, leading to an assumption of disjoint reference, but not coreference (as in his other example (12b), reproduced as (10), where the definite lexical NP the man is most naturally understood as referring to some other 'man' than 'John'):

(10) $\mathrm{John}_{1}$ came in and the $\operatorname{man}_{2}$ sat down. (Levinson, 2000: example (12b), p. 181)

What is inducing the M-implicature of disjoint reference between 'John' and 'the man' in (10) is the fact that the speaker could well have used a pronoun (and even, more naturally still, a zero subject) in place of the more prolix NP the man to achieve a coreferential reading with John, but did not. But in the previous example (9), the speaker could also have chosen a pronoun (but not, in this context, a zero subject) in place of the lexically more explicit the ship to indicate coreference with the ferry, but did not.

Yet in (9), both the clear default "Cause-Consequence" relation holding between the two events evoked (where 'ferry' is a hyponym of 'ship') in terms of the general knowledge that hitting a rock could well cause a ferry to 'capsize', are sufficient to rule out the M-implicature of non-coreference that would otherwise obtain. Moreover, in (10) there is no necessary entailment or default knowledge connection holding between the two events denoted by each conjunct, relating 'John' and 'man' via hyponymy, or synonymy; ${ }^{\mathrm{xv}}$ and the context does not require the referent 'John' to have 'sat down' after 'coming in'. So there is no compelling contextual semantic-pragmatic reason to exclude the M-implicature to non-coreference here.

But a small change to (10), inducing a particular coherence relation (Narration, for example) linking the two events evoked by the two conjuncts, would make a coreferential interpretation more plausible (it would be even more natural if the anaphor were a pronominal epithet, such as the idiot). Yet even without the temporal connective then, the conjunction and coordinating two clauses denoting events may give rise to this implicature, as is well known:

(10) a $\mathrm{John}_{1}$ came in and then the $\operatorname{man}_{1} /$ the idiot 1 sat down.

\footnotetext{
xiv Identical subscript numbers indicate intended coreference here, in virtue of the hyperonymic relation 'if $x$ is a ferry, then $x$ is a ship'.

${ }^{x v}$ Even though the individual designated via John, a conventional name of a male person, could well be characterized as a 'man'.
} 
The key factor in the choice of meta principle ( $\mathrm{I}$ or M) inducing one or other generalized conversational implicature here is whether or not the use of a more minimal expression, such as a pronoun or a zero, would have had the same referential value as the more prolix one. If it would, then the M-implicature will not apply; yet if it would not, then it would (other things being equal). Another factor in addition to those we have seen above is clearly linked to the syntactic-semantic context in which each of the relevant NPs occurs in Levinson's two examples: a distinct, independent sentence in the case of the I-induced coreferential reading of the ship in (9), and the second conjunct within a coordination in (10) in the case of the M-induced disjoint reading of the NP the man. So the connection between antecedent and anaphoric clause is much 'tighter', grammatically speaking, in (10) than in (9) - a factor which inhibits the use of a prolix lexical anaphor in retrieving the referent evoked by the first conjunct (see Bolinger, 1979 and Huang, 2000: 245-6 on this point). ${ }^{\text {xvi }}$

This kind of inhibiting effect induced by local syntactic and semantic factors on the applicability of the I- and M-Principles is highlighted by both Huang (2000) and Blackwell (1998), (2000), (2001) and (2003). Blackwell (1998: 613-614, item (30)) lists the following such factors:

(11) Constraints on I- and M-Implicatures

a. grammatical constraints on coreference (e.g. agreement, c-command; binding principles, distributional constraints)

b. antecedent salience or "in-focus" status

c. assumptions of mutual knowledge of speaker and addressee

d. general semantic constraints including encyclopedic and lexical and semantic entailments

In Blackwell (2001: 939), the author ranks these constraints as follows, separating out the factors "semantic entailments" and "general semantic constraints" in (11d):

(12) Semantic entailments $>$ General semantic constraints $>$ Background knowledge $>$ Antecedent salience $>$ Choice of linguistic alternates

The applicability of these constraints is motivated via the results of a test in which a series of audio-recorded examples involving potentially ambiguous indexical expressions of various sorts (zero subjects, non-clitic reflexive pronouns, overt $3^{\text {rd }}$ person pronouns and definite lexical NPs) was administered to 105 native speakers of Castilian Spanish, who had to choose one from a set of three possible referents for the anaphor type concerned. Interestingly, it was most often a (local) coreferential interpretation which was chosen, often regardless of the type of anaphor used.

Constraint (11d) is proposed by Huang (2000: 215, item (4.30)(b)(iii)) as a range of ways in which an M-contrast between marked and unmarked alternates may be overridden (see also Blackwell, 1998: 616). But this would not necessarily be sufficient in itself to distinguish between Levinson's (2000) examples (9), where the default knowledge-based relation of "Cause-Consequence" obtains between the clause evoking 'a ferry' and the one designating 'a ship', and where coreference is the most natural interpretation, and (10), where no such relation necessarily obtains between the conjunct

xvi This difference in tightness of connection is reflected in the impossibility of a zero subject for the second sentence in (9), as against the complete naturalness of such a realization of the subject of the second conjunct in (10). 
designating 'John' and the one evoking 'the man', and where coreference is claimed not to be intended (via the application of the M-Principle) - unless, for example, a more specific connective is inserted, such as then in (10a). Other factors must then be at work in inhibiting the applicability of the M-Principle, resulting in I-implicatures of coreference.

Let us look at some of the (im)possible pronoun-definite lexical NP alternations in our sample English texts in this respect (see also the more detailed discussion of text (2) in $\S 3.2$ in this regard).

First of all, a segment from text (2) (lines 2-3):

...the decision by St Tropez town council to shut down one of the resort's most celebrated institutions...

The coreferential interpretation between St Tropez and the resort here may be put down to the encyclopedic knowledge that the city of St Tropez is a (seaside) resort on the French Riviera (see the first part of constraint (11d) - i.e. "Background knowledge" in (12)). Another factor may be syntactic: the parallel syntactic functions between $S t$ Tropez in pre-nominal determiner or modifier position within the antecedent expression, and the genitive prehead position adopted by the lexical anaphor the resort. Another, central, factor here is the fact that the pronominal determiner its would not have been possible in place of the lexical NP the resort, since it would most naturally have picked up the more salient referent 'St Tropez town council'. So in any case, the M-Principle would have been inapplicable here.

Let us look now at text (6), where there are a large number of coreferential instances of definite lexical NPs. First, the segment in lines 7-8:

(14) ...I noticed small kids and tourists walking to where the water had receded, curious as to why the water had gone...

Here, unlike in the extract given in (13) from text (2), a pronoun (it) would have been natural under a coreferential interpretation, so the M-principle should apply. But the second definite lexical NP is clearly most naturally understood as coreferential with the identical NP the water in the initial main clause of this extract. Here, the predicative contexts of each reference are such as to induce a coreferential reading, since had receded and had gone are virtually synonymous in this context. This would suffice to rule out the M-induced implicature of non-coreference.

Furthermore, in para (viii) (line 15), a definite lexical NP (the wave) is used in place of a pronoun (which would in fact have been less than natural here):

(15) ...It wasn't moving very quickly, it took between four and five minutes until I saw it hit $\varnothing$ and in that time slowly people started to realise what was happening. People were saying 'Oh God, what is THAT?' I thought I was dreaming. After a few seconds the wave hit $\varnothing$ and $\varnothing$ smashed against the beach...

The lack of a real choice here between the lexical NP the wave and a pronoun it ruling out the applicability of the M-principle in this case, is not due to the salience in context of the intended referent (which is indeed the macro-topic at this point in the discourse). Rather, it is due to a purely discourse-structural factor: the fact that the introduction of 'the tsunami wave' by the narrator in lines $9-11$ has been interrupted by his reference to 
the incredulous reactions of the people around him at the time (People were saying 'Oh God, what is THAT?'). This is a direct-speech report, which as such momentarily shifts the locutionary source. In returning to the main line of narration of the sequence of events after it, there is a need to "reset the cursor" to the macro-topic. This need is further strengthened by the fact that the direct-speech quotation just given in line 14 has stressed the difficulty the bystanders faced at the time in characterizing (categorizing, more properly) what they were witnessing: this is highlighted precisely by their use of the stressed distal demonstrative pronoun THAT within an interrogative construction. In discourse terms, this reference will not yet have been ratified by the hearer or reader at this point in the texts (or so the narrator assumes) - a state of affairs which calls for a lexically explicit rather than purely pronominal reference. This is a specifically discourse relationship also ruling out the M-implicature to non-coreference,

In (15) (see also (16) below), zero pronouns occur. These are of course even more minimal, in terms of form, than $3^{\text {rd }}$ person pronouns. As such, they are treated by Levinson (2000:285, item (26)) as forming a scale termed "the general anaphora pattern". This predicts that, where either expression type may occur in a given position in a text, the zero is more likely to I-implicate co-reference with some antecedent, and the overt pronoun to M-implicate disjoint reference. But as I showed in Cornish (2007: 212-214: see also in particular examples (22a-g), p. 211), this is by no means always the case. In any case, the zero pronoun does not have the same type of reference as the overt pronoun. This may be seen in (15) and (16), where the object of hit has a diffuse, quasideictic value in context, and is perfectly natural. Use of the overt pronoun it here would require a specific anchor point, since it would need to pick up a salient entity available via the context. Yet no such referent is available at the point of use here. Levinson's "general anaphora pattern" would not seem able to predict this difference, which is in a sense the reverse of what would be predicted - the overt pronoun seeking an anaphoric type of interpretation, and the zero pronoun a deictic one.

Another such instance, involving the same referent, occurs on line 20 of text (6):

(16) Most disturbing was I saw people literally disappear when the water hit $\varnothing$.

Here, the pronoun it could well have occurred in place of the prolix definite lexical NP the water, given this referent's high saliency and topicality as macro topic of the text as a whole. And yet its interpretation in context is coreferential rather than evoking some other body of water. Here we clearly see the semantic consistency constraint in action, ${ }^{\text {xvii }}$ as well as the "antecedent saliency" constraint. However in this case, we are not dealing with a relation between two textually explicit NPs in the co-text, but with the relation between a definite lexical NP and a salient discourse representation upstream.

Blackwell (2001: 939) claims (quite rightly in my view) that "listeners often rely more readily on their semantic and pragmatic knowledge of language than on the type of NP expression used anaphorically by the speaker." I would add to her list of relevant constraints, given as (12) above, the nature of what is predicated of the anaphor's referent by the predicative component of the anaphoric clause. It is very interesting that she should place Levinson's choices between "linguistic alternates" at the very end of

\footnotetext{
xvii What is predicated of the referent concerned, together with the reader's knowledge of the world: namely that a wave the size of a tsunami could well cause the "literal disappearance" of people in the area at the time.
} 
the rank scale of types of consistency constraints used by her subjects in the test materials. This means, of course, that it is the lexical-semantic, syntactic and discourselevel constraints placed to the left of this item which take priority over it - and we have amply seen this priority at work in the three texts analyzed above.

When the "antecedent" is not even co-present in the text together with the anaphor, or when it is a global topic entity (as an example, see the extract in (16) from text (6), in its original context), coreference relations may be specified, but not in either GB Binding theory or Levinsonian terms. Such cases require in my view a principled distinction between the dimensions of text and discourse, the relevance of which I have tried to argue for in several publications (see also Widdowson, 2004: Ch.1). Such instances involve a sometimes complex interaction between these two levels or dimensions of structure.

\section{Conclusions}

The question of how indexicals (anaphors and deictics) function in texts is not only (or even primarily) a 'reference resolution' one, as most work in the field of anaphora still assumes is the case. They also have specific discourse-structuring and -signaling properties.

The range of syntactic, semantic, discourse and encyclopedic factors permitting or inhibiting given anaphoric or deictic interpretations of indexical expressions in context, together with the specific discourse-pragmatic instructions associated with each distinct type of such expressions, seem adequate to characterize the values they may assume. Heuristic procedures such as those systematized into Levinson's (2000) I- and M-principles supposedly followed by speakers and their addressees in determining the likely interpretations of various types of indexical, only come into play, if at all, as a last resort — when all else fails, as it were —, as Blackwell's (2001) hierarchy of constraints on interpretation reproduced in (12) shows. This is indeed the case with all the examples drawn from texts (2) and (6) which we examined in section 4; and even Levinson's own illustrative examples, given as (9) and (10), may be accounted for in this way, without invoking his M-principle. Huang's (2000:303) claim that "anaphoric distribution in discourse can largely be determined by the systematic interaction of our Q-, M- and I-principles" is not supported by the present study, since the majority of instances of definite lexical and demonstrative NPs we have examined are not analyzable in terms of the M-principle via a contrast with an alternative $3^{\text {rd }}$ person pronoun - but rather as a function of independently needed discourse-structure principles and constructs.

Yet another condition neutralizing the applicability of the M-principle is the occurrence of the indexical at points of transition in a text. As we have seen, $3^{\text {rd }}$ person pronouns and zeros tend not to occur here, even though their intended referent is highly salient psychologically at these points in the discourse. Instead, it is lexically more specific expressions (e.g. definite NPs, proper nouns or demonstrative-based expressions) capable of fulfilling a demarcating function, that tend to occur in such positions. So the possibility of a choice at these points is ruled out.

Demonstrative-based expressions with a deictic function (pure deictic or discourse-deictic) also realize certain specific discourse functions in texts: see for example the two very similar universally-quantified proximal demonstrative NPs occurring in texts (2) and (6) (lines 13 and 55, respectively) which contribute to shifting the reference from the specific referent(s) in focus in the immediately preceding unit or sub-unit to a more general one, and thereby to heralding the introduction of a new unit 
or sub-unit. Though it is not demonstrative-based (since it is phonetically null), the zero subject of sounds in line 21 of text (4) may also be analyzed as fulfilling this kind of demarcating function (in conjunction with its host verb and what is predicated to its right, of course) - but this is a marked occurrence.

$3^{\text {rd }}$ person pronouns and zeros occur in unit-medial positions in terms of discourse structure, and almost never in initial ones, since they invariably function only locally (cf. Fox, 1987). (One notable exception, however, is the "discourse deictic" zero subject of the verb sound heading unit 4 in text (4) (para vii) just mentioned).

In sum, rather than conceiving the reference potential of given indexicals "atomistically", in terms of binary intra-textual relations between expressions in a cotext, as Levinson and Huang do, it is more fruitful to view this as both determined by and contributing to the macro- as well as micro-discourse structure being created via the text in conjunction with an appropriate context.

\section{Acknowledgement}

This is a revised and expanded version of a paper entitled "Text-type and anaphor-type distribution in terms of discourse-functional units: a comparison", presented at the international Symposium Comparing Anaphors - between Sentences, Texts and Languages, which was held at the Faculty of Language, Communication and Cultural Studies, Copenhagen Business School, Frederiksberg, Copenhagen $\left(1^{\text {st }}-3^{\text {rd }}\right.$ September 2005). I am very grateful to the audience at the presentation for the useful discussion which followed. The text of this paper appeared in the Proceedings of this Symposium edited by I. Korzen and L. Lundquist, vol 34 of Copenhagen Studies in Language published by Samfundslitteratur Press, Copenhagen, pp. 4566

\section{References}

Blackwell, Sarah E., 1998. Constraints on Spanish NP anaphora: the syntactic versus the pragmatic domain. Hispania 81(3), 606-618.

Blackwell, Sarah E., 2000. Anaphora interpretations in Spanish utterances and the neoGricean pragmatic theory. Journal of Pragmatics 32, 389-424.

Blackwell, Sarah E., 2001. Testing the neo-Gricean pragmatic theory of anaphora: the influence of consistency constraints on interpretations of coreference in Spanish. Journal of Pragmatics 33, 901-941.

Blackwell, Sarah E., 2003. Implicatures in Discourse. The case of Spanish NP anaphora. John Benjamins, Amsterdam \& Philadelphia.

Bock, Kathryn, Cutler, Anne, Eberhard, Kathleen M., Butterfield, Sally, Cooper Cutting, J., Humphreys, Karin, R. 2006. Number agreement in British and American English: disagreeing to agree collectively. Language 82(1), 64-113.

Bolinger, Dwight, 1979. Pronouns in discourse. In: Givón, T. (ed.) Syntax and Semantics 12: Discourse and Syntax. Academic Press, New York, pp. 289-310.

Bosch, Peter, 1983. Agreement and Anaphora. A study of the role of pronouns in syntax and discourse. Academic Press, London.

Conte, Maria-Elisabetha, 1992. Deixis textuelle et Deixis am Phantasma. In: Anschütz, S.R. (Ed.), Texte, Sätze, Wörter und Moneme. Festscrift für Klaus Heger zum 65. Geburtstag. Heidelberger Orientverlag, Heidelberg, pp. 153-161.

Cornish, Francis, 1999. Anaphora, Discourse and Understanding. Evidence from English and French. Clarendon Press, Oxford.

Cornish, Francis, 2003. The roles of (written) text and anaphor-type distribution in the construction of discourse. Text 23(1), 1-26. 
Cornish, Francis, 2007. Ch. 9: Implicit internal arguments, event structure, predication and anaphoric reference. In: Hedberg, N., Zacharski, R. (Eds.) The GrammarPragmatics Interface. Essays in honor of Jeanette K. Gundel. John Benjamins, Amsterdam/Philadelphia, pp. 189-216.

Ehlich, Konrad, 1982. Anaphora and deixis: same, similar, or different? In: Jarvella, R. J., Klein, W. (Eds.) Speech, Place and Action. Studies in deixis and related topics. John Wiley, Chichester, pp. 315-338.

Fetzer, Anita, 2004. Recontextualizing Context. John Benjamins, Amsterdam/Philadelphia.

Fox, Barbara A., 1987. Discourse Structure and Anaphora: Written and conversational English. Cambridge University Press, Cambridge.

Francis, Gill, 1986. Anaphoric Nouns. English Language Research, Birmingham.

Givón, Talmy, 2005. Context as Other Minds. The pragmatics of sociality, cognition and communication. John Benjamins, Amsterdam/Philadelphia.

Gumperz, John J., 1992. Contextualization and understanding. Ch. 8 in: Duranti, A., Goodwin, C. (Eds), Rethinking Context. Language as an interactive phenomenon, Cambridge University Press, Cambridge, pp. 229-252.

Hanks, William F., 1992. The indexical ground of deictic reference. In: Duranti, A., Goodwin, C. (Eds.), Rethinking Context: Language as an Interactive Phenomenon. Cambridge University Press, Cambridge, pp. 43-76.

Heurley, Laurent, 1997. Processing units in written texts: paragraphs or information blocks? Ch. 9 in Costermans, J., Fayol, M. (Eds.), Processing Interclausal Relationships. Lawrence Erlbaum Associates, New Jersey, pp. 179-199.

Huang, Yan, 2000. Anaphora: A Cross-linguistic Study. Oxford University Press, Oxford.

Jaszczolt, Kasia, M., 2005. Default Semantics. Foundations of a Compositional Theory of Acts of Communication. Oxford University Press, Oxford.

Kleiber, Georges, 1994. Anaphores et pronoms. Duculot, Louvain-la-Neuve.

Levinson, Stephen C., 2000. Presumptive Meanings. The Theory of Generalized Conversational Implicature. MIT Press, Cambridge, Mass.

Levinson, Stephen C., 2004. Deixis. In: Horn, L.R., Ward, G. (Eds.), The Handbook of Pragmatics. Blackwell Publishing, Malden, MA, USA/Oxford, UK/Carlton, Australia, pp. 97-121.

Lyons, John, 1975. Deixis as the source of reference. In: Keenan, E. (Ed.), Formal Semantics of Natural Language. Cambridge University Press, Cambridge, pp. 61-83.

Lyons, John, 1977. Semantics, Vol. 2. Cambridge University Press, Cambridge.

Parisi, D., Castelfranchi, C., 1977. The discourse as a hierarchy of goals. Signs of Change 1(2), 31-67.

Schnedecker, Catherine, 1997. Nom propre et chaînes de référence. Klincksieck, Paris.

Webber, Bonnie-Lee, 1991. Structure and ostension in the interpretation of discourse deixis. Language and Cognitive Processes 6(2), 107-135.

Widdowson, Henry G., 2004. Text, Context, Pretext. Critical issues in Discourse Analysis. Blackwell, Oxford. 